\title{
Assessing Cephalopods Fisheries in the Strait of Sicily by Using Poor Data Modeling
}

\author{
Michele L. Geraci, ${ }^{1,2}$ Fabio Falsone ${ }^{2 *}$, Vita Gancitano ${ }^{2}$, Danilo Scannella ${ }^{2}$, \\ Fabio Fiorentino ${ }^{2}$ and Sergio Vitale ${ }^{2}$ \\ 1 Geological and Environmental Sciences (BiGeA) - Marine Biology and Fisheries Laboratory of Fano (PU), Department \\ of Biological, University of Bologna, Bologna, Italy, ${ }^{2}$ Institute for Marine Biological Resources and Biotechnology (IRBIM), \\ National Research Council - CNR, Mazara del Vallo, Italy
}

OPEN ACCESS

Edited by:

Simone Libralato,

Istituto Nazionale di Oceanografia e di

Geofisica Sperimentale, Italy

Reviewed by:

Francesco Tiralongo,

University of Catania, Italy

Natalie Anne Dowling,

Oceans and Atmosphere (CSIRO),

Australia

*Correspondence:

Fabio Falsone

fabio.falsone@irbim.cnr.it

Specialty section:

This article was submitted to Marine Ecosystem Ecology,

a section of the journal

Frontiers in Marine Science

Received: 17 July 2020 Accepted: 02 November 2021 Published: 25 November 2021

Citation:

Geraci ML, Falsone F

Gancitano V, Scannella D, Fiorentino $F$ and Vitale $S$ (2021) Assessing Cephalopods Fisheries in the Strait of Sicily by Using Poor Data Modeling. Front. Mar. Sci. 8:584657. doi: 10.3389/fmars.2021.584657
Cephalopods, including octopuses, squids, and cuttlefishes, are exploited by both bottom trawl and small-scale fisheries (SSF) in most of the Mediterranean areas. Bottom trawl fisheries regard cephalopods as a valuable bycatch, whereas for SSF, they are among the main target species. Cephalopods account for a relatively small proportion of the total landings in the Mediterranean. However, from an economic point of view, four cephalopods, Eledone cirrhosa, Eledone moschata, Octopus vulgaris, and Sepia officinalis, account for approximately $15 \%$ of the total landing value. Despite their economic importance, there are very few stock assessments of cephalopods in the Mediterranean because it is difficult to assess them by classical age-based methods, given their short life-cycles, and highly variable growth and recruitment. The production of E. cirrhosa, E. moschata, Illex coindettii, Loligo vulgaris, O. vulgaris, S. officinalis, and Todaropsis eblanae in the waters off the south of Sicily accounts for approximately $8 \%$ of the total Mediterranean yield of cephalopods. This study presents the first attempt to assess the state of these cephalopods in the Strait of Sicily by using surplus production models. Since species-wise landing statistics may be unreliable because of their morphological similarity, some octopuses (E. cirrhosa and E. moschata) and ommastrephid squids (I. coindetii and T. eblanae) were assessed combined. Landing data and abundance indices from trawl surveys were used to describe cephalopod stock dynamics through the Bayesian State Space Schaefer model (BSM) and Surplus Production model in Continuous Time (SPiCT) models. As survey data were not considered reliable indicators of their abundance, O. vulgaris, S. officinalis, and L. vulgaris stocks were assessed using the Catch-Maximum Sustainable Yield (CMSY) model. Overall, squid and cuttlefish stocks were observed to be in healthy conditions. However, assessments of octopus stocks indicated that their condition was critical or recovering. Here, we discuss the different stock statuses in the light of evolving fisheries and environmental factors in the area over time. Although cephalopods are not a priority in the current management system of Mediterranean fisheries, the importance of these species in the food web and their relevance for SSF underline their importance and their exploitation status should be periodically evaluated.

Keywords: stock assessment, surplus production models (SPM), maximum sustainable yield (MSY), fisheries
management, catch-maximum sustainable yield (CMSY), Bayesian surplus production model (BSM), surplus production in continuous time (SPiCT) 


\section{INTRODUCTION}

Cephalopods, both as predators and prey, are key components of marine ecosystems (Boyle and Rodhouse, 2005). Furthermore, commercially important cephalopods are relatively few in number but they support several fisheries, both inshore and offshore, in many oceanic regions (Pierce and Portela, 2014; Rodhouse et al., 2014; Lishchenko et al., 2021). Most cephalopods important to fisheries are semelparous, fast-growing, short-lived, and early maturing species with several cohorts overlapping in the year and their life cycle phenologies are strongly affected by environmental factors (Jackson and O'Dor, 2001; Rodhouse et al., 2014; Jereb et al., 2015; Lishchenko et al., 2021).

In the last few decades, an increasing trend in cephalopod catch from commercial fisheries has been observed in some oceanic regions of the world, together with a progressive decline in groundfish stocks (Rodhouse et al., 2014; Arkhipkin et al., 2015, 2021; Hilborn et al., 2021). This trend has been attributed to several factors: increased biomass in response to global warming (Sauer et al., 2019), reduced competition for prey, and predation by depleted groundfish (Caddy and Rodhouse, 1998; Rodhouse et al., 2014; Doubleday et al., 2016). There is no consensus on the impact of fisheries on cephalopod stocks, with some authors highlighting their vulnerability (e.g., Rosenberg et al., 1990) and others suggesting that their "life-strategy" may be advantageous under heavy fishing pressures relative to long-lived and late-maturing fish (e.g., Caddy, 1983). On the other hand, there is a general agreement on the impact of environmental factors on cephalopod growth and recruitment, and that these affect significant population dynamics and stock assessment parameters (e.g., Rodhouse et al., 2014).

In the Mediterranean Sea, cephalopod fisheries date back to ancient times and can be traced to the Bronze Age, as depicted by Minoic potteries. In this area, cephalopods are fished by both bottom trawl and small-scale fisheries (SSF), where the latter employ gears such as trammel nets, pots, and hand-lines (Quetglas et al., 2015; Falsone et al., 2020). However, most commercial landings are currently attributed to bottom trawling (Sartor et al., 1998; Jereb et al., 2015). The waters south of Sicily [Geographical Sub Area (GSA) 16, according to the FAO General Fishery Commission for the Mediterranean (GFCM)], corresponding to the northernmost sector of the Strait of Sicily, are among the most productive areas for demersal fisheries in the Mediterranean (Milisenda et al., 2017; Di Lorenzo et al., 2018; Falsone et al., 2020). The landings of the following seven species accounted for approximately $8 \%$ of the total Mediterranean landings for cephalopods (FAO Fisheries and aquaculture software, 2021): horned octopus Eledone cirrhosa (Lamarck, 1798), Musky octopus Eledone moschata (Lamarck, 1798), broadtail shortfin squid Illex coindettii (Verany, 1839), European squid Loligo vulgaris (Lamarck, 1798), common octopus, Octopus vulgaris (Cuvier, 1797), common cuttlefish Sepia officinalis (Linnaeus, 1758), and lesser flying squid Todaropsis eblanae (Ball, 1841).

Despite their economic importance, studies assessing cephalopod fisheries and stock status in the Mediterranean are rather scarce. In this region, some cephalopods are caught by SSF, which are intrinsically difficult to monitor, whereas in bottom trawling, these species are generally regarded as bycatch. Moreover, although cephalopod landings are recorded in most Mediterranean countries, they are registered at the family or the genus levels due to difficulties in species identification. Another factor hampering the stock assessment of cephalopods is their life history traits (short lifespans, semelparous reproduction, high natural mortality rates, rapid and often non-asymptotic growth, complex population structures, and weak stock-recruitment relationships). These factors, together with the resource intensive work needed for direct age estimation, make the use of traditional age-based models impractical (Arkhipkin et al., 2021).

The difficulties in undertaking stock assessment are reflected in the poor management of fisheries that exploit cephalopods in the Mediterranean. To the best of the authors' knowledge, technical measures to regulate cephalopod fisheries have been adopted for common octopus only in Tunisia. According to Ezzeddine and El Abed (2004), between 16 May to 15 October of each year, it is forbidden to fish individuals weighing less than $1 \mathrm{~kg}$. In this context, data-poor methods prove to be useful tools for assessing the stock status of these fishery resources. In this study, a Bayesian State Space Schaefer model (BSM), a Catch Maximum Sustainable Yield (CMSY) model (Froese et al., 2017), and a stochastic Surplus Production model in Continuous Time (SPiCT) (Pedersen and Berg, 2017), widely used within the International Council for the Exploration of the Sea (ICES) and GFCM framework, were used to assess the stock status of E. cirrhosa, E. moschata, I. coindettii, L. vulgaris, O. vulgaris, S. officinalis, and T. eblanae in the South of Sicily (GSA 16, Figure 1).

\section{MATERIALS AND METHODS}

\section{Data Sources}

Data were gathered through the European Data Collection Framework. In particular, two main data sources were used: (i) official landing data of SSF and bottom trawl, and (ii) survey data from the International bottom trawl survey in the Mediterranean (MEDITS) (Bertrand et al., 2002; Spedicato et al., 2019). Specieswise landing data could be affected by several factors, including species misidentification and the joint selling of different species. In this study, to cope with these difficulties, some species were assessed as combined species: (i) E. cirrhosa and E. moschata were assessed as Eledone spp. (hereinafter referred to as Eledone), and (ii) I. coindetii and T. eblanae were assessed together (hereinafter referred to as Todill). For the purpose of this study, the analyzed dataset spanned 2004 to 2018 for both landings and MEDITS data. The MEDITS surveys were carried out mainly in springsummer, except for 2013 (carried out in summer-autumn), 2014, and 2017 (carried out in autumn). Accordingly, in the analysis, the biomass indices were standardized to account for the time variability of the trawl surveys. In particular, for each species, the BioIndex (Zupa et al., 2021) and BioStand (Zupa et al., 2020) routines were used to fit General Additive Models (GAMs) with Gaussian distribution (identity link), including years, months, depth, latitude, and longitude as predictive 


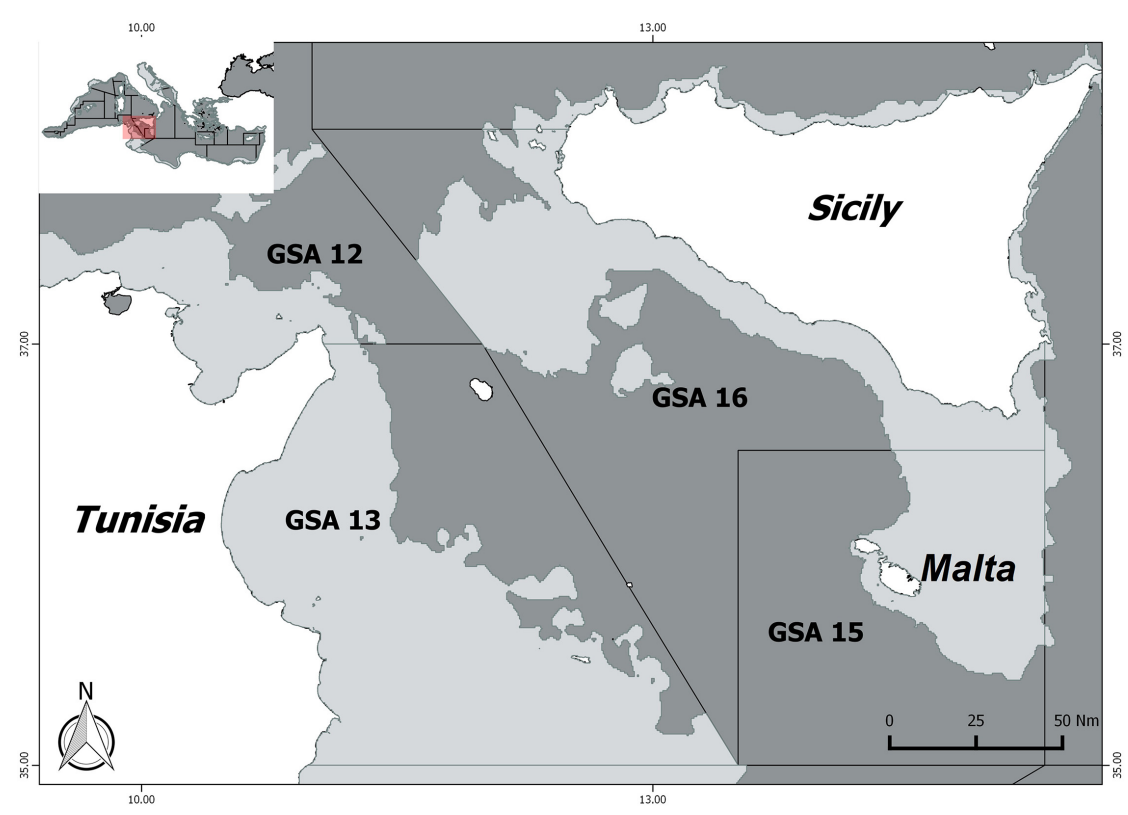

FIGURE 1 | Geographical Sub-Area 16, south of Sicily, where the data of the considered cephalopods were collected.

TABLE 1 | Prior ranges for parameter $r$ used by CMSY and SPICT models.

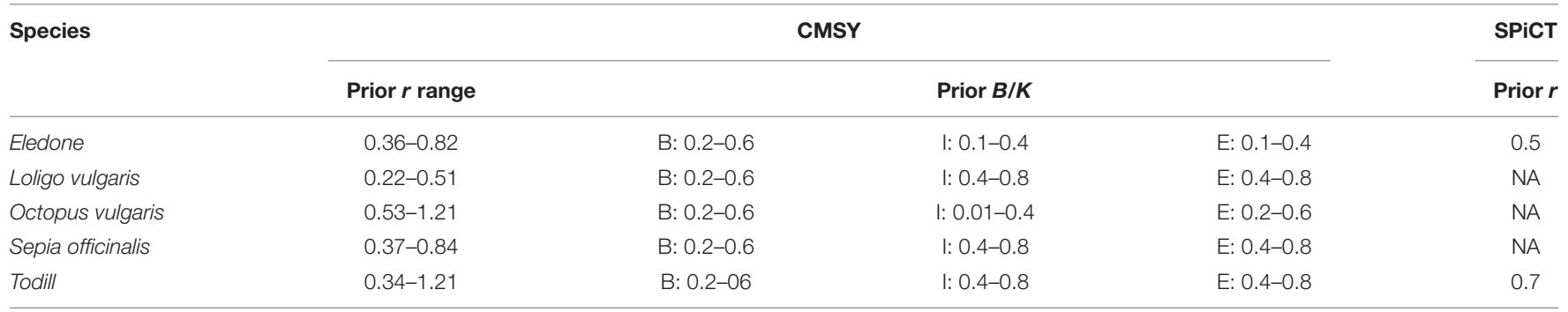

In addition, biomass ranges B/K used by CMSY. In prior ranges B/K, B stands for Beginning; I, for intermediate; E, for End of the time series; NA, not available.

variables. The variables that contributed to improving the model fitting were selected through a stepwise approach, with the most parsimonious model selected through Akaike Information Criterion (AIC), Generalized Cross Validation (GCV), and the percentage of deviance explained (Zuur et al., 2009).

\section{Selection of Models}

Depletion models are considered the most comprehensive and versatile tools for assessing cephalopods (Arkhipkin et al., 2021). However, these models require high-frequency (daily, weekly, monthly) catch and effort data that may not be available for all types of cephalopod fisheries. Therefore, some alternative data-limited approaches have been suggested to assess cephalopod stock status, including catch-only models and Surplus Production Models (SPMs) (Arkhipkin et al., 2021). Many authors have applied these kinds of models for stock assessment of cephalopods worldwide; for example: (i) CMSY and BSM by Froese et al. (2018) and Wang et al. (2020), (ii) AMSY by Froese et al. (2020) and Tsikliras et al. (2021), (iii) SPiCT by ICES (2020), (iv) ASPIC by Mohsin et al. (2020), and (v) Biomass Dynamic Model with environmental effects by ICES (2017).
In the present study, cephalopod stock status was assessed using SPMs, i.e., CMSY, BSM, and SPiCT. The choice to apply SPMs was mainly dictated by the availability of annual landings and surveys of biomass indices data only. These models might seem unsuitable for cephalopods, given that they assume a constant carrying capacity, which is unlikely for a species whose recruitment and growth can vary widely according to environmental conditions (Rodhouse et al., 2014; Arkhipkin et al., 2021). However, it is worth noting that if input data have enough contrast to allow the model fitting, and main environmental drivers, such as sea surface temperature (SST) or primary production, fluctuate throughout time without any clear trend, the assumption of a carrying capacity as the mean size of an unexploited population could be considered reasonable. Nonetheless, these considerations do not exclude the assumption that a constant carrying capacity cannot be violated. Moreover, CMSY, BSM, and SPiCT require less data than other catch-only data-poor assessment methods (Dowling et al., 2018; Falsone et al., 2021) making them suitable for assessing cephalopod species. For example, the DepletionCorrected Average Catch (DCAC) method (MacCall, 2009) 
TABLE 2 | Selected GAM models with the predictive variables used for the standardization of the surveys indices.

\begin{tabular}{|c|c|c|c|c|}
\hline Species & Model & $\mathbf{R}^{2}$ & Dev.expl.\% & GCV \\
\hline Eledone cirrhosa & $\mathrm{BI} \sim$ year $+\mathrm{s}(\mathrm{X}, \mathrm{Y})+\mathrm{s}($ depth $)+$ month +0 & 0.445 & 60.1 & 1.65 \\
\hline Eledone moschata & $\mathrm{Bl} \sim$ year $+\mathrm{s}(\mathrm{X}, \mathrm{Y})+\mathrm{s}($ depth $)+0$ & 0.556 & 73.4 & 2.46 \\
\hline Illex coindettii & $\mathrm{BI} \sim$ year $+\mathrm{s}(X, Y)+\mathrm{s}($ depth $)+0$ & 0.580 & 74.5 & 1.99 \\
\hline Todaropsis eblanae & $\mathrm{BI} \sim$ year $+\mathrm{s}(\mathrm{X}, \mathrm{Y})+\mathrm{s}($ depth $)+0$ & 0.519 & 64.7 & 1.86 \\
\hline
\end{tabular}

BI, Biomass Index; X, longitude; Y, latitude; s, smooth function; Dev. expl. \%, deviance explained as percentage; GCV, Generalized Cross Validation.

requires information on catch, relative depletion, natural mortality (M), and $\mathrm{F}_{M S Y} / \mathrm{M}$ as inputs, while the Stock Synthesis Data-Limited (SS-DL) method (Cope, 2013) in the catch data configuration requires several additional basic biological and selectivity assumptions. On the other hand, the Catch-OnlyModel with Sampling Importance Resampling (COM-SIR) (Vasconcellos and Cochrane, 2005) and State-Space Catch-Only Model (SSCOM) methods (Thorson et al., 2013) require catch, and priors for resilience $(r)$ and carrying capacity $(K)$ as inputs. Also, they are generally based on the same population dynamics assumptions (e.g., constant carrying capacity) as assumed by CMSY, BSM, and SPiCT.

\section{Catch-Maximum Sustainable Yield Model}

The CMSY model allows the computation of stock descriptors and parameters given the population's resilience and catches. Species resilience is defined as the "measure of a species ability to adapt to changes in variable states, driving influences and parameters, and still persist" (Holling, 1973). The CMSY approach derives from the Catch-MSY method by Martell and Froese (2012) but addresses several shortcomings of its predecessor by including biased estimation of unexploited stock size and productivity, adding estimation of biomass and exploitation rates, and optimization of the underlying Monte Carlo algorithm. One of the recent improvements of CMSY is the implementation of a Bayesian state-space Schaefer surplus production model (BSM) as a routine tool within the CMSY package (Froese et al., 2017). Unlike CMSY, BSM also requires catch-per-unit-effort or other relative abundance indices (Froese et al., 2017) to perform the assessment. Both models are based on the dynamic formula of the Schaefer model (Equation 1):

$$
B_{t+1}=B_{t}+r\left(1-\frac{B_{t}}{K}\right) B_{t}-C_{t}
$$

where $\mathrm{B}_{t+1}$ is the exploited biomass in year $t+1, \mathrm{~B}_{t}$ is the biomass in year $t, r$ is the intrinsic rate of population increase, $K$ is the carrying capacity (i.e., the mean unexploited stock size), and $\mathrm{C}_{t}$ is the catch in year $t$. Both models account for depensation or reduced recruitment at severely depleted stock sizes, incorporating a linear decline of surplus production (Myers et al., 1995; Schnute and Richards, 2002) (Equation 2):

$$
B_{t+1}=B_{t}+4 \frac{B_{t}}{K} r\left(1-\frac{B_{t}}{K}\right) B_{t}-C_{t} \frac{B_{t}}{K}<0.25
$$

Specifically, a hockey-stick function is combined with the production model by introducing a multiplier which decreases linearly from 1 to zero at biomass below $0.25 \mathrm{~K}$ (Beverton and Holt, 1957; Ricker, 1975; Barrowman and Myers, 2000). This multiplier provides more realistic estimates of $r$ and $K$ in stocks with extended periods of severely depleted biomass. It also removes the bias in the CMSY estimates of final biomass in severely depleted stocks (Froese et al., 2017). Among the five cephalopod stocks, Eledone and Todill were assessed using both fishery dependent and independent data (i.e., BSM). In the case of $L$. vulgaris, O. vulgaris, and S. officinalis, only landing data (i.e., CMSY) was used because of the poor trawl survey performance in sampling the population at sea. The different levels of exploitation in terms of $\mathrm{F} / \mathrm{F}_{M S Y}$ and $\mathrm{B} / \mathrm{B}_{M S Y}$ were classified by using the threshold reported by Demirel et al. (2020): severely depleted ( $\left.\mathrm{B} \leq 0.2 \mathrm{~B}_{M S Y}\right)$, critical condition $\left(\mathrm{B} \leq 0.5 \mathrm{~B}_{M S Y}, \mathrm{~F}>\mathrm{F}_{M S Y}\right)$, exploited outside safe biological limits $\left(\mathrm{B} \leq 0.5 \mathrm{~B}_{M S Y}\right)$, subject to overfishing $\left(\mathrm{F}>\mathrm{F}_{M S Y}\right)$, recovering $\left(\mathrm{B}<\mathrm{B}_{M S Y}, \mathrm{~F} \leq \mathrm{F}_{M S Y}\right)$, and healthy $\left(\mathrm{B}>\mathrm{B}_{M S Y}, \mathrm{~F} \leq \mathrm{F}_{M S Y}\right)$.

\section{Prior Selection}

Priors for $r$ were derived from SeaLifeBase ${ }^{1}$ (Palomares and Pauly, 2019) for invertebrates. The prior ranges for $k$ were based on Equations (3) and (4) for stocks with low and high prior biomass at the end of the time series, respectively.

$$
\begin{gathered}
K_{\text {low }}=\frac{\max (C)}{r_{\text {high }}} ; K_{\text {high }}=\frac{4 \max (C)}{r_{\text {low }}} \\
K_{\text {low }}=\frac{2 \max (C)}{r_{\text {high }}} ; K_{\text {high }}=\frac{12 \max (C)}{r_{\text {low }}}
\end{gathered}
$$

where $K_{\text {low }}$ and $K_{\text {high }}$ are the lower and upper bounds of the prior range of $K, \max (C)$ is the maximum catch in the time series, and $r_{\text {low }}$ and $r_{\text {high }}$ are the lower and upper bounds of the $r$ range to be explored by the Monte Carlo algorithm of the CMSY. Both BSM and CMSY models require prior estimates of relative biomass $(\mathrm{B} / \mathrm{K})$ at the beginning and end of the time series, and optionally also in the middle. The rules for setting prior biomass ranges are mostly derived from patterns in catch, that is, the timing and ratio of minimum catch to maximum catch, following the approach of Froese et al. (2017; Table 1). Priors were calculated by applying to the catch data a 3 -year moving average in order to reduce the influence of extremes.

\section{Surplus Production Model in Continuous Time Model}

The SPiCT model (Pedersen and Berg, 2017) is a fully stochastic version of the traditional Pella-Tomlinson biomass

\footnotetext{
${ }^{1}$ www.sealifebase.org
} 

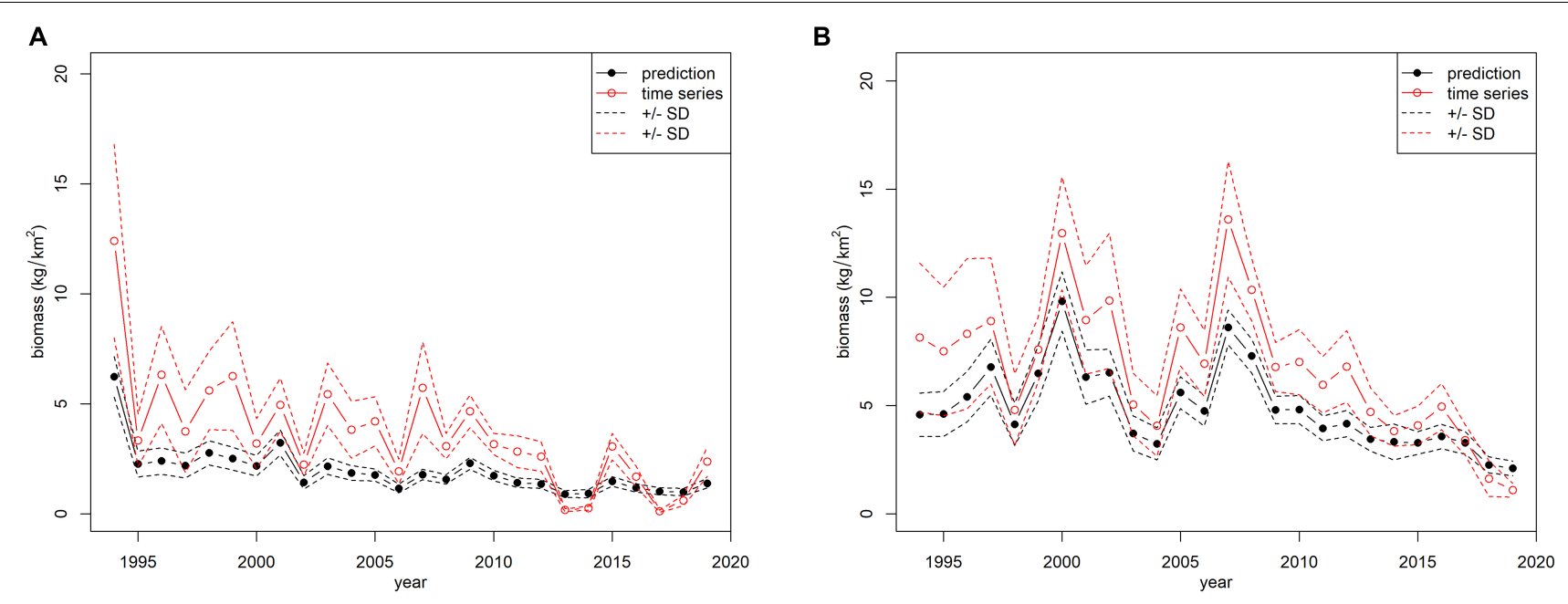

C

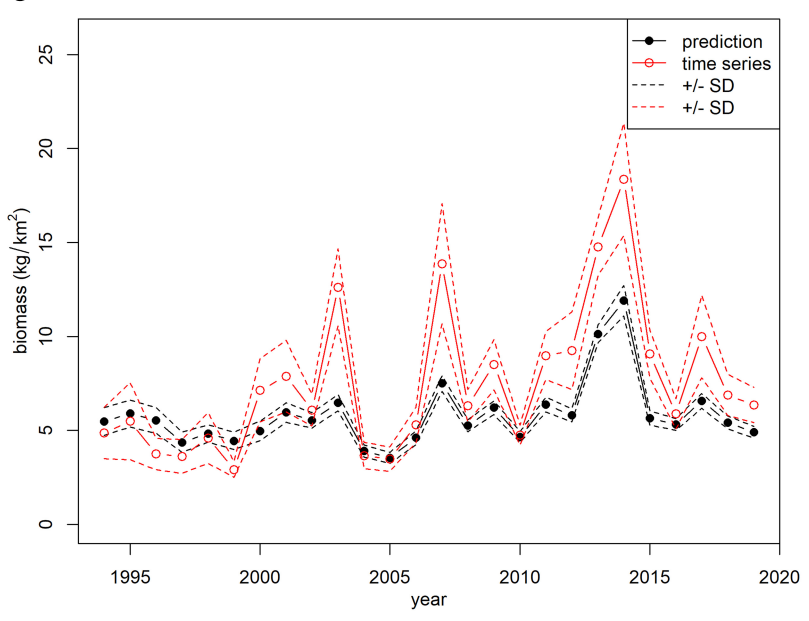

D

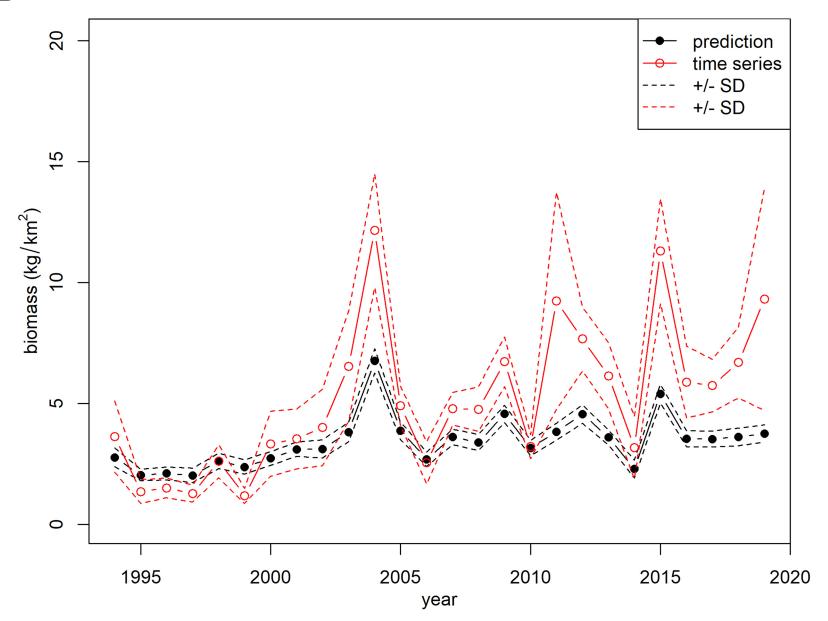

FIGURE 2 | Comparison between the observed (red lines) and standardized (black lines) biomass indices ( $\mathrm{kg} / \mathrm{km}^{2}$ ) of the MEDITS survey from the south of Sicily (GSA16): (A) Eledone cirrhosa; (B) Eledone moschata; (C) Illex coindetii; (D) Todaropsis eblanae.

dynamic model (Pella and Tomlinson, 1969). It uses the reparameterization of Fletcher (1978) and is formulated as a stochastic differential equation (SDE) that includes process noise:

$$
d B_{t}=\left(y m \frac{B_{t}}{K}-y m\left[\frac{B_{t}}{K}\right]-F_{t} B_{t}\right) d t+\sigma_{B} B_{t} d W t
$$

where $\mathrm{y}=\mathrm{n}^{n /(n-1)} /(\mathrm{n}-1), \mathrm{B}_{t}$ is the exploitable biomass at time $t, K$ is the carrying capacity, $m$ is the productivity parameter, and represents the maximum attainable surplus production (MSY), $\mathrm{n}$ determines the shape of the production curve, $\sigma_{B}$ is the standard deviation of the process noise, and $\mathrm{dW}_{t}$ is the Brownian motion. The SPiCT model allows the implementation of the Pella-Tomlinson biomass dynamic model for skewed production curves and includes the Schaefer $(n=2$; Schaefer, 1954) and Fox ( $n=1$; Fox, 1970) models as special cases. For the purpose of the present study, the $n$ parameter was set equal to 2, that is, the Schaefer production curve. The SPiCT assumptions are: (i) the analyzed stock is not subject to migration (i.e., closed population), (ii) $\mathrm{B}_{t}$ is the exploitable stock biomass, (iii) there are no lagged effects in the dynamics of $\mathrm{B}_{t}$, (iv) the catchability in the survey and fishery are constant over the years, and (v) there is no particular pattern of recruitment. For other technical details (see Pedersen and Berg, 2017; Mildenberger et al., 2020). The same priors for $r$ used for the CMSY and BSM approaches were used for the SPiCT model (Table 1). In particular, the SPiCT model was fitted to the Eledone and the Todill stocks. As with CMSY and $\mathrm{BSM}$, the different levels of exploitation in terms of $\mathrm{F} / \mathrm{F}_{M S Y}$ and $\mathrm{B} / \mathrm{B}_{M S Y}$ were classified using the thresholds reported by Demirel et al. (2020).

\section{RESULTS}

\section{Biomass Standardization}

The models and predictive variables used to standardize survey indices are shown in Table 2. In particular, all models considered 


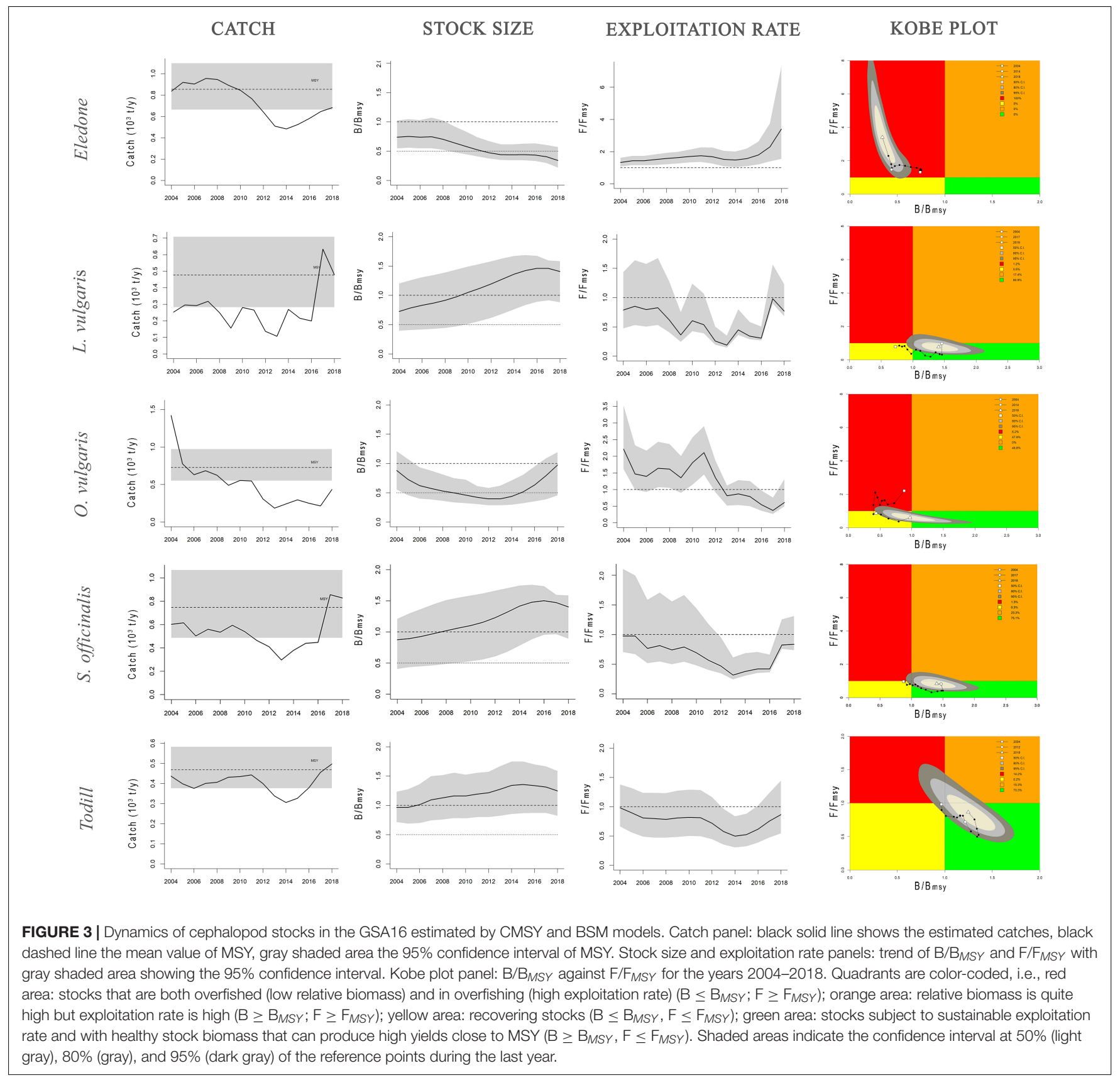

year, geographical coordinates (X: longitude, Y: latitude), and depth as predictive variables, except for E. cirrhosa for which month was also included as a predictor. The standardized and observed trawl survey indices are shown in Figure 2.

\section{Stock Dynamics}

Stock dynamics have been described in terms of species-wise catch $\left(10^{3}\right.$ tons), relative stock size $\left(\mathrm{B} / \mathrm{B}_{M S Y}\right)$, and exploitation rate $\left(\mathrm{F} / \mathrm{F}_{M S Y}\right)$. The main aspects of the stock status by species have been synthetically shown as a Kobe plot $\left(\mathrm{F} / \mathrm{F}_{M S Y}\right.$ against $\mathrm{B} / \mathrm{B}_{M S Y}$, Figure 3). The main outputs of the BSM, CMSY, and SPiCT models are listed in Table 3. Table 4 shows a comparison of the results obtained in this study with the cephalopod stock assessments carried out in other Mediterranean areas.

The general results seem to highlight that octopus stocks were in a critical and/or recovering condition, whereas squid stocks were in a healthy condition. Detailed results regarding the stock status of each taxon are provided below.

\section{Eledone}

BSM and SPiCT yielded similar estimates of Eledone stock status. In particular, $\mathrm{BSM}$ estimated a $\mathrm{B} / \mathrm{B}_{M S Y}$ ratio equal to 0.3 [confidence interval $(\mathrm{CI})=0.2-0.6]$ and $\mathrm{F} / \mathrm{F}_{M S Y}$ of 3.4 (1.57.3). SPiCT estimates were $0.5(0.2-1.7)$ and $1.5(0.6-3.6)$ for 


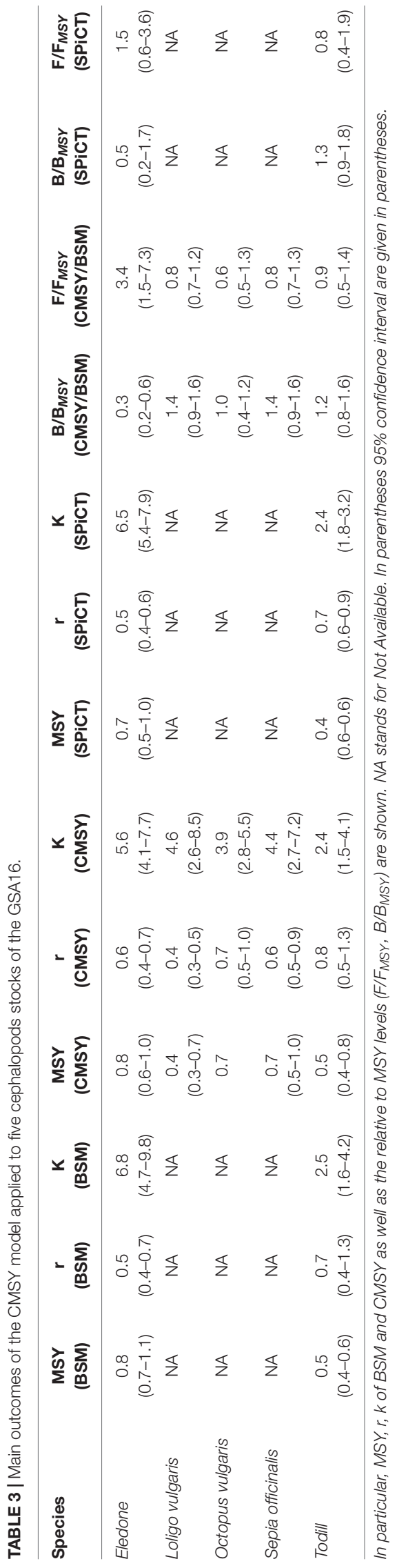

$\mathrm{B} / \mathrm{B}_{M S Y}$ and $\mathrm{F} / \mathrm{F}_{M S Y}$, respectively. In addition, the estimated values for K, MSY and $r$ were very similar between models (BSM: $\mathrm{K}=6.8 \times 10^{3}$ tons, $\mathrm{CI}: 4.7-9.8 ; \mathrm{MSY}=0.8 \times 10^{3}$ tons, $\mathrm{CI}$ : $0.7-1.1 ; r=0.5, \mathrm{CI}=0.4-0.7$. SPiCT: $\mathrm{K}=6.5 \times 10^{3}$ tons, $\mathrm{CI}$ : 5.4-7.9; $\mathrm{MSY}=0.7 \times 10^{3}$ tons, $\mathrm{CI}: 0.5-1.0 ; r=0.5, \mathrm{CI}=0.4-$ $0.6)$. Both models indicated a decrease in stock size $\left(\mathrm{B} / \mathrm{B}_{M S Y}\right)$ over the years and an increase in the fishing mortality $\left(\mathrm{F} / \mathrm{F}_{M S Y}\right)$ in recent years, although this was more markedly observed in BSM. However, the perception of the stock during the first years of the time series is different, with SPiCT showing an increase, while BSM shows a decrease in stock size. Lastly, even though there was high uncertainty in stock status, especially for SPiCT, this was in critical condition for Eledone according to both models ( $\mathrm{B} \leq 0.5 \mathrm{~B}_{M S Y}, \mathrm{~F}>\mathrm{F}_{M S Y}$; Figures 3, 4 and Tables 3, 4).

\section{European Squid}

Assessment results indicated that European squid have been in a recovering condition since the beginning of the time series $\left(\mathrm{B}<\mathrm{B}_{M S Y}, \mathrm{~F} \leq \mathrm{F}_{M S Y}\right)$. In the last 2 years, the $\mathrm{F} / \mathrm{F}_{M S Y}$ ratio increased and the $\mathrm{B} / \mathrm{B}_{M S Y}$ slightly decreased; however, the stocks could be considered in good condition (healthy state, $\mathrm{B}>\mathrm{B}_{M S Y}, \mathrm{~F} \leq \mathrm{F}_{M S Y}$ ). It is worth highlighting that the CMSY estimates are characterized by low uncertainty i.e., $\mathrm{B} / \mathrm{B}_{M S Y}=1.4$ with $\mathrm{CI}=0.9$ 1.6 and $\mathrm{F} / \mathrm{F}_{M S Y}=0.8$ with $\mathrm{CI}=0.7-1.2$ (Figure 3 and Tables 3, 4).

\section{Common Octopus}

The stock of common octopus showed the same trend as that of the European squid, with an overall improvement through the time series from an initial critical condition $\left(\mathrm{F}>\mathrm{F}_{M S Y}\right.$ and $\left.\mathrm{B} \leq 0.5 \mathrm{~B}_{M S Y}\right)$ to a recovering state ( $\mathrm{B}<\mathrm{B}_{M S Y}$ and $\mathrm{F} \leq \overline{\mathrm{F}}_{M S Y}$ ) during the last year, very close to that of the healthy condition $\left(\mathrm{B}>\mathrm{B}_{M S Y}\right.$ and $\mathrm{F} \leq \mathrm{F}_{M S Y}$ ). The CMSY estimated a $\mathrm{B} / \mathrm{B}_{M S Y}=1.0$ with $\mathrm{CI}=0.4-$ 1.2 and $\mathrm{F} / \mathrm{F}_{M S Y}=0.6$ with $\mathrm{CI}=0.5-1.3$ (Figure 3 and Tables 3, 4).

\section{Common Cuttlefish}

The common cuttlefish stock was initially in a recovering status $\left(\mathrm{B}<\mathrm{B}_{M S Y}, \mathrm{~F} \leq \mathrm{F}_{M S Y}\right)$. In the last few years (2017-2018), the relative fishing mortality increased and the relative biomass slightly decreased, even though the species was still in a healthy status at the end of the time series (B $>\mathrm{B}_{M S Y}, \mathrm{~F} \leq \mathrm{F}_{M S Y}$ ). The uncertainty of the CMSY model was very low, i.e., $\mathrm{B} / \mathrm{B}_{M S Y}=1.4$ with $\mathrm{CI}=0.9$ 1.6 and F/FMSY $=0.8$ with $\mathrm{CI}=0.7-1.3$ (Figure 3 and Tables 3, 4).

\section{Todill}

$\mathrm{BSM}$ estimated a $\mathrm{B} / \mathrm{B}_{M S Y}$ ratio equal to $1.2(\mathrm{CI}=0.8-1.6)$ and $\mathrm{F} / \mathrm{F}_{M S Y}$ of $0.9(0.5-1.4)$. SPiCT estimated $1.3(0.9-1.8)$ and $0.8(0.4-1.9)$ for $\mathrm{B} / \mathrm{B}_{M S Y}$ and $\mathrm{F} / \mathrm{F}_{M S Y}$, respectively. In addition, the estimated carrying capacity, MSY, and $r$ were very similar between models (BSM: $\mathrm{K}=2.5 \times 10^{3}$ tons, $\mathrm{CI}$ : $1.6-$ 4.2; $\mathrm{MSY}=0.5 \times 10^{3}$ tons, CI: $0.4-0.6 ; r=0.7, \mathrm{CI}=0.4-1.3$; SPiCT: $\mathrm{K}=2.4 \times 10^{3}$ tons, $\mathrm{CI}: 1.8-3.2 ; \mathrm{MSY}=0.4 \times 10^{3}$ tons, CI: $0.3-0.6 ; r=0.7, \mathrm{CI}=0.6-0.9)$. However, in the first 2 
TABLE 4 | Synopsis of the cephalopod assessments carried out in Mediterranean stocks.

\begin{tabular}{|c|c|c|c|c|c|c|c|c|}
\hline Species & Area & $\mathbf{r}$ & $\mathbf{K}$ & $\mathrm{B} / \mathrm{B}_{M S Y}$ & $\mathbf{F} / \mathbf{F}_{M S Y}$ & Status & Model & Authors \\
\hline \multirow[t]{6}{*}{ Eledone cirrhosa } & Ligurian Sea & 1.3 & 0.3 & $0.7(0.5-0.9)$ & $1.0(0.8-1.3)$ & $\mathrm{R}$ & ASPIC & Abella et al., 2010 \\
\hline & Ligurian Sea & NA & NA & NA & NA & $\mathrm{H}^{*}$ & $\mathrm{Y} / \mathrm{R}$ & Orsi Relini et al., 2006 \\
\hline & southern Tyrrhenian Sea & NA & NA & NA & NA & $\mathrm{O}^{\star \star}$ & Y/R & Giordano et al., 2010 \\
\hline & central Tyrrhenian Sea & NA & NA & NA & NA & $\mathrm{H}^{*}$ & Y/R & Agnesi et al., 1998 \\
\hline & Aegean Sea & NA & NA & 0.1 & 0.9 & $\mathrm{R}$ & AMSY & Tsikliras et al., 2021 \\
\hline & Ionian Sea & NA & NA & 0.4 & 4.5 & C & CMSY & Froese et al., 2018 \\
\hline \multirow[t]{2}{*}{ Eledone moschata } & Aegean Sea & NA & NA & 0.7 & 0.9 & $\mathrm{R}$ & CMSY & Froese et al., 2018 \\
\hline & Aegean Sea & NA & $\mathrm{NA}$ & 0.7 & 1.3 & $\mathrm{O}$ & AMSY & Tsikliras et al., 2021 \\
\hline \multirow[t]{2}{*}{ Eledone } & Strait of Sicily & 0.5 & 6.8 & $0.3(0.2-0.6)$ & $3.4(1.5-7.3)$ & $\mathrm{C}$ & $\mathrm{BSM}$ & Present study \\
\hline & Strait of Sicily & 0.5 & 6.5 & $0.5(0.2-1.7)$ & $1.5(0.6-3.6)$ & C & SPiCT & Present study \\
\hline \multirow[t]{5}{*}{ Illex coindettii } & Ionian Sea & NA & NA & 0.6 & 0.6 & $\mathrm{O}$ & CMSY & Froese et al., 2018 \\
\hline & Adriatic Sea & NA & NA & 0.3 & 1.1 & C & CMSY & Froese et al., 2018 \\
\hline & Sardinia & NA & NA & 0.6 & 1.1 & $\mathrm{O}$ & CMSY & Froese et al., 2018 \\
\hline & Aegean Sea & NA & NA & 0.8 & 1.3 & $\mathrm{O}$ & CMSY & Froese et al., 2018 \\
\hline & Adriatic Sea & NA & NA & $1.1(0.6-2.0)$ & $0.7(0.1-1.7)$ & $\mathrm{H}$ & AMSY & Froese et al., 2020 \\
\hline \multirow[t]{7}{*}{ Loligo vulgaris } & Strait of Sicily & 0.4 & 4.6 & $1.4(0.9-1.6)$ & $0.8(0.7-1.2)$ & $\mathrm{H}$ & CMSY & Present study \\
\hline & Balearic Island & NA & NA & NA & NA & NA & $\mathrm{DM}$ & Keller et al., 2015 \\
\hline & Adriatic Sea & NA & NA & 0.2 & 0.9 & $D$ & CMSY & Froese et al., 2018 \\
\hline & Aegean Sea & NA & NA & 0.6 & 1.3 & $\mathrm{O}$ & CMSY & Froese et al., 2018 \\
\hline & Balearic Islands & NA & NA & 0.4 & 1.1 & $\mathrm{C}$ & CMSY & Froese et al., 2018 \\
\hline & Gulf of Lions & NA & NA & 0.3 & 3.1 & $\mathrm{C}$ & CMSY & Froese et al., 2018 \\
\hline & Sardinia & NA & NA & 0.3 & 2.8 & $\mathrm{C}$ & CMSY & Froese et al., 2018 \\
\hline \multirow[t]{7}{*}{ Octopus vulgaris } & Strait of Sicily & 0.7 & 3.9 & $1.0(0.4-1.2)$ & $0.6(0.5-1.3)$ & $\mathrm{H}-\mathrm{R}$ & CMSY & Present study \\
\hline & Adriatic Sea & NA & NA & $1.0(0.6-1.8)$ & $0.9(0.3-1.7)$ & $\mathrm{H}-\mathrm{R}$ & AMSY & Froese et al., 2020 \\
\hline & Balearic Island & 0.6 & 0.7 & $0.4(0.3-0.6)$ & $1.2(0.9-1.5)$ & C & SPM & Quetglas et al., 2015 \\
\hline & Aegean Sea & NA & $\mathrm{NA}$ & 0.5 & 1.1 & C & CMSY & Froese et al., 2018 \\
\hline & Ionian Sea & NA & $\mathrm{NA}$ & 0.3 & 1.2 & C & CMSY & Froese et al., 2018 \\
\hline & Gulf of Lions & NA & NA & 0.8 & 1.3 & $\mathrm{O}$ & CMSY & Froese et al., 2018 \\
\hline & Levantine Sea & NA & $\mathrm{NA}$ & 0.1 & 0.9 & $\mathrm{D}$ & CMSY & Demirel et al., 2020 \\
\hline \multirow[t]{15}{*}{ Sepia officinalis } & Strait of Sicily & 0.6 & 4.4 & $1.4(0.9-1.6)$ & $0.8(0.7-1.3)$ & $\mathrm{H}$ & CMSY & Present study \\
\hline & Adriatic Sea & NA & NA & 0.5 & 2.1 & $\mathrm{C}$ & CMSY & Froese et al., 2018 \\
\hline & Aegean Sea & NA & NA & 0.6 & 0.9 & $\mathrm{R}$ & CMSY & Froese et al., 2018 \\
\hline & Balearic Islands & NA & NA & 0.3 & 2.7 & C & CMSY & Froese et al., 2018 \\
\hline & Ionian Sea & NA & NA & 0.8 & 1.4 & $\mathrm{O}$ & CMSY & Froese et al., 2018 \\
\hline & Gulf of Lions & NA & NA & 0.3 & 1.8 & C & CMSY & Froese et al., 2018 \\
\hline & Sardinia & NA & NA & 0.8 & 1.2 & $\mathrm{O}$ & CMSY & Froese et al., 2018 \\
\hline & Adriatic Sea & NA & NA & $0.6(0.3-0.9)$ & $0.8(0.6-1.6)$ & $\mathrm{R}$ & $\mathrm{BSM}$ & Armelloni et al., 2018 \\
\hline & Balearic Sea & NA & NA & NA & NA & NA & $\mathrm{DM}$ & Maynou, 2015 \\
\hline & Balearic Sea & NA & NA & NA & NA & NA & $\mathrm{DM}$ & Keller et al., 2015 \\
\hline & Balearic Sea & 0.8 & 0.2 & $0.6(0.4-0.8)$ & $1.1(0.9-1.4)$ & O & SPM & Quetglas et al., 2015 \\
\hline & Cyprus & NA & NA & $1.3(0.7-2.3)$ & $0.6(0.0-1.6)$ & $\mathrm{H}$ & AMSY & Froese et al., 2020 \\
\hline & Egypt & NA & NA & NA & NA & $\mathrm{O}$ & $\mathrm{Y} / \mathrm{R}$ & Mehanna and Haggag, 2011 \\
\hline & Levantine Sea & NA & NA & 0.6 & 1.4 & $\mathrm{O}$ & CMSY & Demirel et al., 2020 \\
\hline & Ligurian Sea & 0.98 & 0.5 & $0.5(0.4-0.7)$ & $1.5(1.3-1.7)$ & C & SPM & Abella et al., 2010 \\
\hline Todaropsis eblanae & Aegean Sea & NA & NA & 1.7 & 0.2 & $\mathrm{H}$ & AMSY & Tsikliras et al., 2021 \\
\hline \multirow[t]{2}{*}{ Todill } & Strait of Sicily & 0.7 & 2.5 & $1.2(0.8-1.6)$ & $0.9(0.5-1.4)$ & $\mathrm{H}$ & BSM & Present study \\
\hline & Strait of Sicily & 0.7 & 2.4 & $1.3(0.9-1.9)$ & $0.8(0.4-1.9)$ & $\mathrm{H}$ & SPiCT & Present study \\
\hline
\end{tabular}

$H$, healthy, $B>B_{M S Y}, F \leq F_{M S Y} ; R$, recovering, $B<B_{M S Y}$ and $F \leq F_{M S Y} ; O$, subject to overfishing, $F>F_{M S Y} ;$, exploited outside safe biological limits $B \leq 0.5 B_{M S Y}$, critical condition, $B \leq 0.5 B_{M S Y}, F>F_{M S Y} ; D$, severely depleted, $B \leq 0.2 B_{M S Y}$.

*Scenario codend mesh size $40 \mathrm{~mm}$; **scenario codend mesh size $20 \mathrm{~mm}$.

years, BSM estimated the stock to be in a recovering condition $\left(\mathrm{B}<\mathrm{B}_{M S Y}\right.$ and $\left.\mathrm{F} \leq \mathrm{F}_{M S Y}\right)$, whereas SPiCT always estimated a healthy condition over the time series $\left(\mathrm{B}>\mathrm{B}_{M S Y}, \mathrm{~F} \leq \mathrm{F}_{M S Y}\right.$;
Figures 3, 4 and Table 3). The uncertainty of both models was higher about the estimated exploitation rates than the stock sizes (Tables 3, 4). 

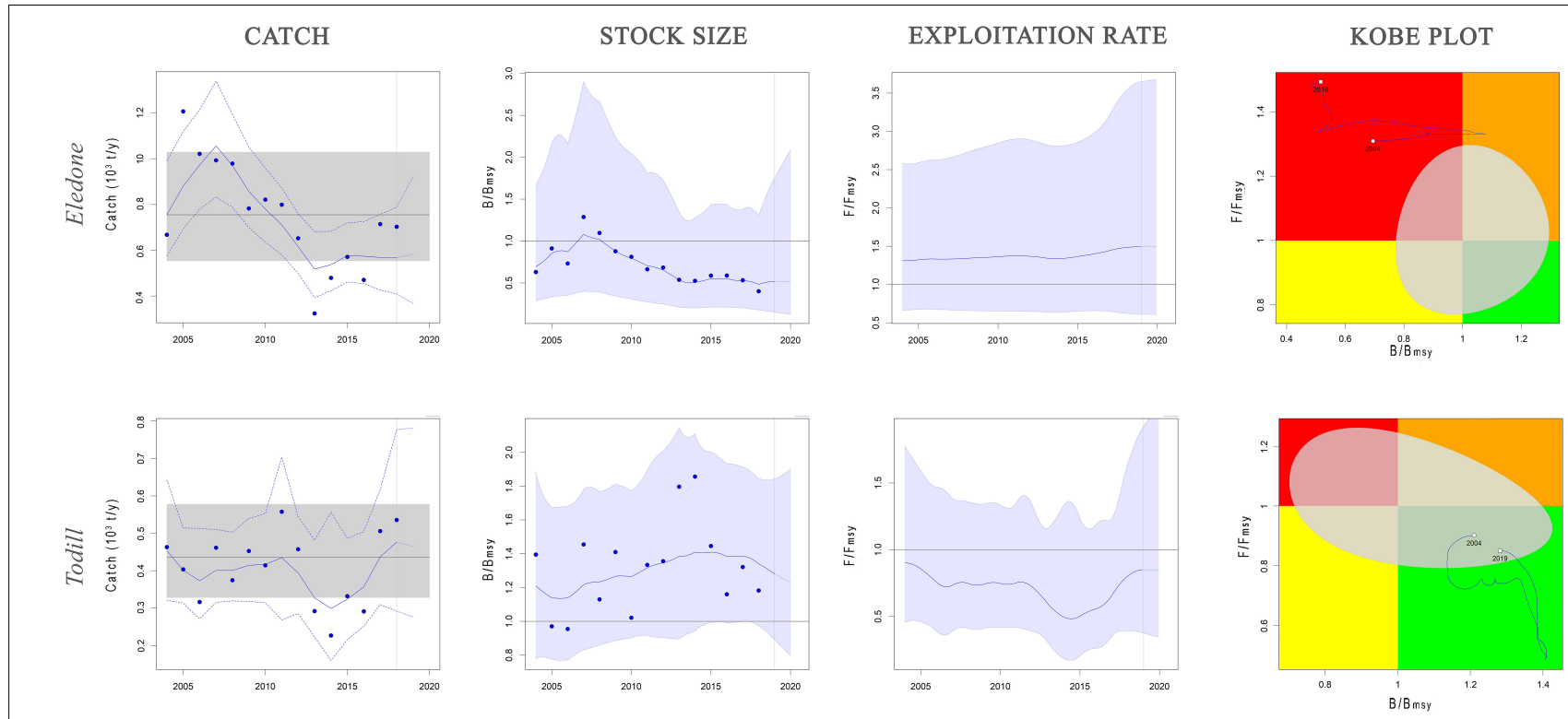

FIGURE 4 | Dynamics of Eledone and Todill stocks estimated by SPiCT model. Catch panel: blue solid line shows the estimated catches, blue dashed lines the 95\% confidence interval of the estimated catches, black solid line the mean value of MSY and gray shaded area the $95 \%$ confidence interval of MSY. Stock size and exploitation rate panels: trend of $\mathrm{B} / \mathrm{B}_{M S Y}$ and $\mathrm{F} / \mathrm{F}_{M S Y}$, with the light blue area showing the $95 \%$ confidence interval. Kobe plot panel: B/B $\mathrm{B}_{M S}$ against $\mathrm{F} / \mathrm{F}_{M S Y}$ ratios for the years with available data (2004-2018). Quadrants are color-coded, i.e., red area: stocks that are both overfished (low relative biomass) and in overfishing (high exploitation rate) $\left(\mathrm{B} \leq \mathrm{B}_{M S Y} ; \mathrm{F} \geq \mathrm{F}_{M S Y}\right)$; orange area: relative biomass is quite high but exploitation rate is high ( $\mathrm{B} \geq \mathrm{B}_{M S Y} ; \mathrm{F} \geq \mathrm{F}_{M S Y}$ ); yellow area: recovering stocks $\left(\mathrm{B} \leq \mathrm{B}_{M S Y}, \mathrm{~F} \leq \mathrm{F}_{M S Y}\right)$; green area: stocks subject to sustainable exploitation rate and with healthy stock biomass that can produce high yields close to MSY $\left(B \geq B_{M S Y}, F \leq F_{M S Y}\right)$. Gray area represents the uncertainty, expressed as 95\% confidence interval, of the reference points.

\section{DISCUSSION}

The lack of contrast in the time series of catch and effort data, the short life cycle and cohort overlapping, and the resource intensive direct age estimation have been the main reasons for the limited cephalopod stock assessments to date (Pierce et al., 2010; Arkhipkin et al., 2021). In their very recent review of stock assessment methods for cephalopods, Arkhipkin et al. (2021) suggested that depletion models are the best tool for modeling the dynamics of cephalopod fisheries. However, the relative lack of interest in cephalopod fisheries in the Mediterranean makes it challenging to gather all the fine temporal scale data needed to run depletion models. Arkhipkin et al. (2021) suggested that in data-limited conditions, the recent developments in SPMs provide a means to investigate the stock status of cephalopods and to provide valid information to support management actions.

In the Strait of Sicily, cephalopods represent a significant fraction of the commercial catch, contributing highly to the profitability of fishers; nevertheless, their stock and fisheries remain largely unassessed and unregulated. In this context, the present study is the first attempt to assess the stock status of commercial cephalopods exploited in the GSA16 through surplus production models.

The assessments undertaken of these cephalopod species available in the Mediterranean showed very diverse stock statuses (Table 4). The critical state of Eledone found in the Strait of Sicily was similar to that reported for its stocks in the Aegean (Tsikliras et al., 2021), Ligurian, and Tyrrhenian Seas (Abella et al., 2010;
Giordano et al., 2010; Froese et al., 2018). On the other hand, Agnesi et al. (1998) reported a healthy stock status of E. cirrhosa in the Tyrrhenian Sea and Orsi Relini et al. (2006) for the Ligurian Sea. The stock status of O. vulgaris in the Strait of Sicily was healthy/recovering, which is in agreement with that reported by Froese et al. (2020) in the Adriatic Sea. Conversely, in other Mediterranean areas, its status ranged from overfishing in the Gulf of Lions (Froese et al., 2018) to severely depleted in the Levantine Sea (Demirel et al., 2020), or critical in the Balearic Islands (Quetglas et al., 2015) and in the Ionian/Adriatic Sea (Froese et al., 2018). As for ommastrephids, the healthy state of Todill found in the Strait of Sicily was similar to that reported for its stocks in the Aegean (Tsikliras et al., 2021) and the Adriatic Seas (Froese et al., 2020). Conversely, Froese et al. (2018) found that the state of the ommastrephid squids varied from "overfished" in the Ionian/Aegean Sea and Sardinia to "critical" in the Adriatic Sea.

The healthy state of $L$. vulgaris estimated in the present study was in contrast with Froese et al. (2018), who reported an overfished stock status in the Aegean Sea, a critical state in the Balearic/Sardinia Islands and the Gulf of Lions, and a severely depleted state in the Adriatic Sea. Concerning S. officinalis, only Froese et al. (2020) indicated a healthy condition of the stock in waters around Cyprus, in agreement with the findings of the present study. In other areas of the Mediterranean, the stock status ranged from recovering in the Adriatic (Armelloni et al., 2018) and the Aegean Seas (Froese et al., 2018) to critical condition in the Adriatic Sea, Balearic Islands, Gulf of Lions 
(Froese et al., 2018), and the Ligurian Sea (Abella et al., 2010); and being in overfishing off the Egyptian coasts (Mehanna and Haggag, 2011), the Balearic Islands (Quetglas et al., 2015), in the Levantine Sea (Demirel et al., 2020), the Ionian Sea, and Sardinia (Froese et al., 2018).

The CMSY and BSM models assume that recruitment is constant above the threshold of 0.25 of the carrying capacity. This condition could not be met for the species considered in this study, potentially affecting the results of the assessment. However, the convergence of results obtained by the BSM and SPiCT models, which do not assume any constraint on recruitment, suggests that the BSM assessments may be robust enough to properly assess species such as cephalopods. However, it should be noted that SPiCT provided more optimistic results than BSM during the initial years of the time series. The stock statuses of the octopods in GSA16 were worse than those of the squids and cuttlefish. These different statuses might be related to differences in biology, behavior, vulnerability to fishing gear, or reaction to abiotic factors. According to Russo et al. (2019), the nominal fishing effort of Italian bottom trawlers in the Strait of Sicily decreased from 2009 to 2016. This reduced fishing pressure on the fishing grounds could have disadvantaged octopuses in competition with demersal fishes. On the other hand, the different responses to the environmental factors could explain the different dynamics between squids, cuttlefish, and octopuses; based on habitat suitability modeling, Lauria et al. (2016) reported that in the Strait of Sicily, I. coindetii prefers warmer and less salty waters, whereas T. eblanae prefers saltier waters. Conversely, both species of Eledone do not seem to be definitively affected by sea water temperature, whereas E. cirrhosa prefers waters characterized by higher salinity. Working at the Mediterranean level, Keller et al. (2017) reported that areas of high sea surface temperature showed higher densities of I. coindetii, while warmer years were coincident with lower O. vulgaris abundance.

SPMs, like most stock assessment models, assume uniform productivity but due to climate change, this assumption may be violated (Bundy et al., 2012; Szuwalski and Hollowed, 2016). Although non-stationary population processes can introduce bias into assessments of target biomass and fishing mortality, few accepted frameworks are available for including the influence of the changing environment on the management strategies of exploited stocks (Szuwalski and Hollowed, 2016).

The present study provides insights into the dynamics of stocks of commercially important cephalopods that are not the main target species of multiannual management plans for fisheries in the Mediterranean. Although it is difficult to provide advice for the management of cephalopod exploitation, especially in the case of multi-species and low-selectivity fisheries, the role of these species in the food web and their relevance for SSF calls

\section{REFERENCES}

Abella, A., Ria, M., and Mancusi, C. (2010). Assessment of the status of the coastal groundfish assemblage exploited by the Viareggio fleet (Southern Ligurian Sea). Sci. Mar. 74, 793-805. doi: 10.3989/scimar.2010.74n4793 for attention to the importance of periodic assessment of their stock dynamics. Moreover, considering that some cephalopods are target species of specific SSFs in the area, the results suggest the need for adopting specific measures for controlling exploitation and enhancing stock status. This is the case for S. officinalis in the Strait of Sicily (Falsone et al., 2020), for which technical measures based on seasonal closure during critical stages, such as the spawning period, could be adopted.

\section{DATA AVAILABILITY STATEMENT}

The raw data supporting the conclusions of this article will be made available by the authors, without undue reservation.

\section{ETHICS STATEMENT}

Ethical review and approval was not required for the animal study because the current methodology not required ethical review and approval.

\section{AUTHOR CONTRIBUTIONS}

SV and FFi: conceptualization and validation. FFa and MG: formal analysis. MG, FFa, DS, and VG: data curation and data collection and figures. MG: writing-original draft. MG, VG, FFa, DS, FFi, and SV: writing-review and editing. All authors contributed to the article and approved the submitted version.

\section{FUNDING}

This work was conducted thanks to the European Data Collection Framework (DCF)-Transversal Variables and MEDITS Survey Modules - funded by the European Union and the Italian Ministry for Agricultural, Food and Forestry Policies.

\section{ACKNOWLEDGMENTS}

The research leading to these results has been conceived under the International Ph.D. Program "Innovative Technologies and Sustainable Use of Mediterranean Sea Fishery and Biological Resources (www.FishMed-PhD.org)." This study represents partial fulfillment of the requirements for the Ph.D. thesis of MG. We would like to thank Editage (www.editage.com) and Dr. Martina Castelli for English language editing. Finally, we would also like to thanks the reviewers and Dr. Luca Ceriola for their significant improvement of the manuscript.

Agnesi, S., Belluscio, A., and Ardizzone, G. D. (1998). Biologia e dinamica di popolazione di Eledone cirrhosa (Cephalopoda: octopoda) nel Tirreno Centrale. Biol. Mar. Med. 5, 336-348.

Arkhipkin, A. I., Hendrickson, L. C., Payá, I., Pierce, G. J., Roa-Ureta, R. H., Robin, J. P., et al. (2021). Stock assessment and management of cephalopods: advances 
and challenges for short-lived fishery resources. ICES J. Mar. Sci. 78, 714-730. doi: 10.1093/icesjms/fsaa038

Arkhipkin, A. I., Rodhouse, P. G. K., Pierce, G. J., Sauer, W., Sakai, M., Allcock, L., et al. (2015). World Squid Fisheries. Rev. Fish. Sci. Aquac. 23, 92-252. doi: 10.1080/23308249.2015.1026226

Armelloni, E. N., Masnadi, F., Scanu, M., Grati, F., Bolognini, L., Polidori, P., et al. (2018). GFCM-WGSAD Scientific Advisory Committee on Fisheries (SAC) WorkingGroup on Stock Assessment of Demersal Species (WGSAD). Rome: FAO

Barrowman, N. J., and Myers, R. A. (2000). Still more spawner-recruitment curves: the hockey stick and its generalizations. Can. J. Fish. Aquat. Sci. 57, 665-676. doi: 10.1139/f99-282

Bertrand, J. A., Gil de Sola, L., Papaconstantinou, C., Relini, G., and Souplet, A. (2002). The general specifications of the MEDITS surveys. Sci. Mar. 66:9. doi: 10.3989/scimar.2002.66s29

Beverton, R. J. H., and Holt, S. J. (1957). On the Dynamics of Exploited Fish Populations. London: Great Britain Ministry of Agriculture, Fisheries and Food.

Boyle, P., and Rodhouse, P(ed.) (2005). "Cephalopods as predators," in Cephalopods-Ecology and Fisheries, (Oxford: Blackwell Publishing), 222-233. doi: 10.1002/9780470995310.ch14

Bundy, A., Bohaboy, E. C., Hjermann, D. O., Mueter, F. J., Fu, C., and Link, J. S. (2012). Common patterns, common drivers: comparative analysis of aggregate surplus production across ecosystems. Mar. Ecol. Prog. Ser. 459, 203-218.

Caddy, J., and Rodhouse, P. (1998). Cephalopod and groundfish landings: evidence for ecological change in global fisheries? Rev. Fish Biol. Fish. 8, 431-444. doi: 10.1023/A:1008807129366

Caddy, J. F. (1983). "The cephalopods: factors relevant to their population dynamics and to the assessment and management of stocks," in Advances in Assessment of World Cephalopod Resources. Fish. Tech. Pap. 231, ed. J. F. Caddy (Rome: FAO), 416-449.

Cope, J. M. (2013). Implementing a statistical catch-at-age model (Stock Synthesis) as a tool for deriving overfishing limits in data-limited situations. Fish. Res. 142, 3-14. doi: 10.1016/j.fishres.2012.03.006

Demirel, N., Zengin, M., and Ulman, A. (2020). First large-scale eastern Mediterranean and Black Sea stock assessment reveals a dramatic decline. Front. Mar. Sci. 7:103. doi: 10.3389/fmars.2020.00103

Di Lorenzo, M., Sinerchia, M., and Colloca, F. (2018). The north sector of the strait of sicily: a priority area for conservation in the Mediterranean Sea. Hydrobiologia 821, 235-253. doi: 10.1007/s10750-017-3389-7

Doubleday, Z. A., Prowse, T. A. A., Arkhipkin, A., Pierce, G. J., Semmens, J., Steer, M., et al. (2016). Global proliferation of cephalopods. Curr. Biol. 26, R406-R407. doi: 10.1016/j.cub.2016.04.002

Dowling, N. A., Smith, A. D. M., Smith, D. C., Parma, A. M., Dichmont, C. M., Sainsbury, K., et al. (2018). Generic solutions for data-limited fishery assessments are not so simple. Fish Fish. 20, 174-188. doi: 10.1111/faf.12329

Ezzeddine, S., and El Abed, A. (2004). Potential Biological and Environmental Influences on the Octopus vulgaris Population of the Gulf of Gabès (SouthEastern Tunisian Coast). MedSudMed Technical Documents, 2. 42-49.

Falsone, F., Scannella, D., Geraci, M. L., Gancitano, V., Vitale, S., and Fiorentino, F. (2021). How fishery collapses: the Case of Lepidopus caudatus (Pisces: Trichiuridae) in the Strait of Sicily (Central Mediterranean). Front. Mar. Sci. 7:1188. doi: $10.3389 /$ fmars.2020.584601

Falsone, F., Scannella, D., Geraci, M. L., Vitale, S., Colloca, F., Di Maio, F., et al. (2020). Identification and characterization of trammel net métiers: a case study from the southwestern Sicily (Central Mediterranean). Reg. Stud. Mar. Sci. 39:101419. doi: 10.1016/j.rsma.2020.101419

FAO Fisheries and aquaculture software (2021). FishStatJ - Software for Fishery and Aquaculture Statistical Time Series. In: FAO Fisheries and Aquaculture Department [online]. Rome: FAO.

Fletcher, R. I. (1978). On the restructuring of the Pella-Tomlinson system. U.S. Fish. Bull. 76, 515-534.

Fox, W. W. (1970). An exponential surplus-yield model for optimizing exploited fish populations. Trans. Am. Fish. Soc. 99, 80-88.

Froese, R., Demirel, N., Coro, G., Kleisner, K. M., and Winker, H. (2017). Estimating fisheries reference points from catch and resilience. Fish Fish. 18, 506-526. doi: 10.1111/faf. 12190

Froese, R., Winker, H., Coro, G., Demirel, N., Tsikliras, A., Dimarchopoulou, D., et al. (2018). Status and rebuilding European Fisheries. Mar. Policy 93, 159-170. doi: $10.1016 /$ j.marpol.2018.04.018
Froese, R., Winker, H., Coro, G., Demirel, N., Tsikliras, A. C., Dimarchopoulou, D., et al. (2020). Estimating stock status from relative abundance and resilience. ICES J. Mar. Sci. 77, 527-538. doi: 10.1093/icesjms/fsz230

Giordano, D., Busalacchi, B., Bottari, T., Perdichizzi, F., Profeta, A., Perdichizzi, A., et al. (2010). Population dynamics and distribution of Eledone cirrhosa (Lamarck, 1798) in the Southern Tyrrhenian Sea (Central Mediterranean). Cah. Biol. Mar. 51, 213.

Hilborn, R., Hively, D. J., Loke, N. B., Moor, C. L., Kurota, H., Kathena, J. N., et al. (2021). Global status of groundfish stocks. Fish and Fish. 22, 911-928. doi: $10.1111 /$ faf. 12560

Holling, C. S. (1973). Resilience and stability of ecological systems. Annu. Rev. Ecol. Syst. 4, 1-23. doi: 10.1146/annurev.es.04.110173.000245

ICES (2017). Report of the Working Group on Cephalopod Fisheries and Life History (WGCEPH), 14-17 June 2016, ICES Headquarters, Copenhagen, Denmark. ICES Document CM 2016/SSGEPD: 03. Copenhagen: ICES, 111.

ICES (2020). Working Group on Cephalopod Fisheries and Life History (WGCEPH; outputs from 2019 meeting). ICES Scientific Reports. 2:46. Copenhagen: ICES, 121. doi: 10.17895 /ices.pub. 6032

Jackson, G. D., and O'Dor, R. K. (2001). Time, space and the ecophysiology of squid growth, life in the fast lane. Vie. Milieu. 51, 205-215.

Jereb, P., Allcock, A. L., Lefkaditou, E., Piatkowski, U., Hastie, L. C., and Pierce, G. J. (eds) (2015). Cephalopod Biology and Fisheries in Europe: II. Species Accounts. ICES Cooperative Research Report No. 325. Copenhagen: ICES.

Keller, S., Quetglas, A., Puerta, P., Bitetto, I., Casciaro, L., Cuccu, D., et al. (2017). Environmentally driven synchronies of Mediterranean cephalopod populations. Prog. Oceanogr. 152, 1-14. doi: 10.1016/j.pocean.2016.1 2.010

Keller, S., Robin, J.-P., Valls, M., Gras, M., Cabanellas-Reboredo, M., and Quetglas, A. (2015). The use of Depletion Methods to assess Mediterranean cephalopod stocks under the current EU Data Collection Framework. Med. Mar. Sci. 16:513. doi: $10.12681 / \mathrm{mms} .1127$

Lauria, V., Garofalo, G., Gristina, M., and Fiorentino, F. (2016). Contrasting habitat selection amongst cephalopods in the Mediterranean Sea: when the environment makes the difference. Mar. Env. Res. 119, 252-266. doi: 10.1016/j. marenvres.2016.06.011

Lishchenko, F., Perales-Raya, C., Barrett, C., Oesterwind, D., Power, A. M., Larivain, A., et al. (2021). A review of recent studies on the life history and ecology of European cephalopods with emphasis on species with the greatest commercial fishery and culture potential. Fish. Res. 236:105847. doi: 10.1016/j. fishres.2020.105847

MacCall, A. D. (2009). Depletion-corrected average catch: a simple formula for estimating sustainable yields in data-poor situations. ICES J. Mar. Sci. 66, 2267-2271. doi: 10.1093/icesjms/fsp209

Martell, S., and Froese, R. (2012). A simple method for estimating MSY from catch and resilience. Fish Fish. 14, 504-514. doi: 10.1111/j.1467-2979.2012.00485.x

Maynou, F. (2015). Application of a multi-annual generalized depletion model to the assessment of a data-limited coastal fishery in the western Mediterranean. Sci. Mar. 79, 157-168. doi: 10.3989/scimar.04173.28a

Mehanna, S. F., and Haggag, H. M. (2011). "Stock assessment of the common cuttlefish, Sepia officinalis in the Southeastern Mediterranean, Egypt," in Proceedings of the 4th Global Fisheries and Aquaculture Research Conference, the Egyptian International Center for Agriculture, Giza, Egypt, 3-5 October 2011 Massive Conferences and Trade Fairs, (Giza), 277-284.

Mildenberger, T. K., Berg, C. W., Pedersen, M. W., Kokkalis, A., and Nielsen, J. R. (2020). Time-variant productivity in biomass dynamic models on seasonal and long-term scales. ICES J. Mar. Sci. 77, 174-187. doi: 10.1093/icesjms/ fsz154

Milisenda, G., Vitale, S., Massi, D., Enea, M., Gancitano, V., Giusto, G. B., et al. (2017). Spatio-temporal composition of discard associated with the deep water rose shrimp fisheries (Parapenaeus longirostris, Lucas 1846) in the southcentral Mediterranean Sea. Med. Mar. Sci. 18, 53-63. doi: 10.12681/mms. 1787

Mohsin, M., Hengbin, Y., Zhuo, C., and Mehak, A. (2020). An assessment of overexploitation risk faced by cephalopod fisheries in China: a non-equilibrium surplus production model approach. Indian J. Geo Mar. Sci. 49, 318-325.

Myers, R. A., Barrowman, N. J., Hutchings, J. A., and Rosenberg, A. A. (1995). Population dynamics of exploited fish stocks at low population levels. Science 269, 1106-1108. doi: 10.1126/science.269.5227.1106 
Orsi Relini, L., Mannini, A., Fiorentino, F., Palandri, G., and Relini, G. (2006). Biology and fishery of Eledone cirrhosa in the Ligurian Sea. Fish. Res. 78, 72-88. doi: 10.1016/j.fishres.2005.12.008

Palomares, M. L. D., and Pauly, D (ed). (2019). SeaLifeBase. World Wide Web Electronic Publication. Available online at: www.sealifebase.org, version (12/2019) (accessed March 15, 2020).

Pedersen, M. W., and Berg, C. W. (2017). A stochastic surplus production model in continuous time. Fish Fish. 18, 226-243. doi: 10.1111/faf.12174

Pella, J. J., and Tomlinson, P. K. (1969). A generalized stock production model. Bull. Int. Am. Trop. Tuna Commission 13, 421-458.

Pierce, G. J., Allcock, A. L., Bruno, I., Bustamante, P., González, Á, Guerra, A., et al. (2010). Cephalopod Biology and Fisheries in Europe. ICES Cooperative Research Report 303. Copenhagen: ICES.

Pierce, G. J., and Portela, J. (2014). "Fisheries production and market demand," in Cephalopod Culture, eds J. Iglesias, L. Fuentes, and R. Villanueva (Berlin: Springer), 41-58. doi: 10.1007/978-94-017-8648-5_3

Quetglas, A., Keller, S., and Massutí, E. (2015). Can Mediterranean cephalopod stocks be managed at MSY by 2020? The Balearic Islands as a case study. Fish. Manag. Ecol. 22, 349-358. doi: 10.1111/fme.12131

Ricker, W. E. (1975). Computation and Interpretation of Biological Statistics of fish Populations. Bulletin of the Fisheries Research Board of Canada 191, Ottawa, Canada. Ontario, OT: Bulletin of the Fisheries Research, 382.

Rodhouse, P. G. K., Pierce, G. J., Nichols, O. C., Sauer, W. H. H., Arkhipkin, A. I., Laptikhovsky, V. V., et al. (2014). Environmental effects on cephalopod population dynamics. Adv. Mar. Biol. 67, 99-233. doi: 10.1016/b978-0-12800287-2.00002-0

Rosenberg, A. A., Kirkwood, G. P., Crombie, J. A., and Beddington, J. R. (1990). The assessment of stocks of annual squid species. Fish. Res. 8, 335-350. doi: 10.1016/0165-7836(90)90003-e

Russo, T., Carpentieri, P., D’Andrea, L., De Angelis, P., Fiorentino, F., Franceschini, S., et al. (2019). Trends in effort and yield of trawl fisheries: a case study from the Mediterranean Sea. Front. Mar. Sci. 6:153. doi: 10.3389/fmars.2019.00153

Sartor, P., Belcari, P., Carboell, A., Gonzalez, M., Quetglas, A., and Sánchez, P. (1998). The importance of cephalopods to trawl fisheries in the western Mediterranean. South Afr. J. Mar. Sci. 20, 67-72. doi: 10.2989/ 025776198784126313

Sauer, W. H. H., Gleadall, I. G., Downey-Breedt, N., Doubleday, Z., Gillespie, G., Haimovici, M., et al. (2019). World Octopus Fisheries. Rev. Fish. Sci. Aquac. 29, 279-429. doi: 10.1080/23308249.2019.1680603

Schaefer, M. B. (1954). Some aspects of the dynamics of populations important to the management of the commercial marine fisheries. Int. Am. Trop. Tuna Commission Bull. 1, 25-56.

Schnute, J. T., and Richards, L. J. (2002). "Surplus production models," in Handbook of Fish Biology and Fisheries, Vol. 2, eds P. J. B. Hart and J. D. Reynolds (Oxford: Blackwell Publishing), 105-126.

Spedicato, M. T., Massutí, E., Mérigot, B., Tserpes, G., Jadaud, A., and Relini, G. (2019). The MEDITS trawl survey specifications in an ecosystem approach to fishery management. Sci. Mar. 83:9. doi: 10.3989/scimar.04915.11x
Szuwalski, C. S., and Hollowed, A. B. (2016). Climate change and non-stationary population processes in fisheries management. ICES J. Mar. Sci. 73, 12971305.

Thorson, J. T., Minto, C., Minte-Vera, C. V., Kleisner, K. M., and Longo, C. (2013). A new role for effort dynamics in the theory of harvested populations and data-poor stock assessment. Can. J. Fish. Aquat. Sci. 70, 1829-1844. doi: 10.1139/cjfas-2013-0280

Tsikliras, A. C., Touloumis, K., Pardalou, A., Adamidou, A., Keramidas, I., Orfanidis, G. A., et al. (2021). Status and exploitation of 74 un-assessed demersal fish and invertebrate stocks in the Aegean Sea (Greece) using abundance and resilience. Front. Mar. Sci. 7:578601. doi: 10.3389/fmars.2020.578601

Vasconcellos, M., and Cochrane, K. (2005). "Overview of world status of data limited fisheries: inferences from landing statistics," in Fisheries Assessment and Management in Data-limited Situations Alaska Sea Grant Programme, eds G. H. Kruse, V. F. Gallucci, D. E. Hay, R. I. Perry, R. M. Peterman, T. C. Shirley, et al. (Fairbanks, AK: University of Alaska Fairbanks), 1-20. doi: 10.4027/famdls. 2005.01

Wang, Y., Liang, C., Wang, Y., Xian, W., and Palomares, M. L. (2020). Stock Status Assessments for 12 Exploited Fishery Species in the Tsushima Warm Current Region, Southwest Japan and East China, Using the CMSY and BSM Methods. Front. Mar. Sci. 7:640. doi: 10.3389/fmars.2020.00640

Zupa, W., Bitetto, I., and Spedicato, M. T. (2020). BioStand v.2.1.3. Torre a Mare: Coispa Tecnologia \& Ricerca - Stazione sperimentale per lo Studio delle Risorse del Mare.

Zupa, W., Casciaro, L., Bitetto, I., and Spedicato, M. T. (2021). BioIndex v.3.0. Torre a Mare: Coispa Tecnologia \& Ricerca - Stazione sperimentale per lo Studio delle Risorse del Mare.

Zuur, A. F., Ieno, E. N., Walker, N., Saveliev, A. A., and Smith, G. M. (2009). Mixed Effects Models and Extensions in Ecology with R. Statistics for Biology and Health, XXII. New York, NY: Springer-Verlag.

Conflict of Interest: The authors declare that the research was conducted in the absence of any commercial or financial relationships that could be construed as a potential conflict of interest.

Publisher's Note: All claims expressed in this article are solely those of the authors and do not necessarily represent those of their affiliated organizations, or those of the publisher, the editors and the reviewers. Any product that may be evaluated in this article, or claim that may be made by its manufacturer, is not guaranteed or endorsed by the publisher.

Copyright (c) 2021 Geraci, Falsone, Gancitano, Scannella, Fiorentino and Vitale. This is an open-access article distributed under the terms of the Creative Commons Attribution License (CC BY). The use, distribution or reproduction in other forums is permitted, provided the original author(s) and the copyright owner(s) are credited and that the original publication in this journal is cited, in accordance with accepted academic practice. No use, distribution or reproduction is permitted which does not comply with these terms. 